\title{
Occurrence and Distribution of Begomoviruses Infecting Cassava in Western Kenya
}

\author{
Mariam Nyongesa Were ${ }^{1}$, Benard Mukoye ${ }^{1,}$, , Aggrey Keya Osogo ${ }^{2}$, Bonphace Collins Mangeni ${ }^{1}$, \\ Paul Ateng'a Nyamwamu, ${ }^{1}$, Vitalis Kalor Ogemah ${ }^{1}$, John Vincent Muoma ${ }^{1}$, Stephan Winter ${ }^{3}$, \\ Hassan Karakacha Were ${ }^{1}$
}

${ }^{1}$ Department of Biological Sciences, Masinde Muliro University of Science and Technology, Kakamega, Kenya

${ }^{2}$ Department of Biological Sciences, Kibabii University, Bungoma, Kenya

${ }^{3}$ Leibniz-Institute DSMZ Plant, Virus Department, Braunschweig, Germany

\section{Email address:}

Claris.nyongesa@yahoo.com (M. N. Were),btemukoye@gmail.com (B. Mukoye), aosogokeya@yahoo.co.uk (A. K. Osogo), barasamangeni@gmail.com (B. C. Mangeni),pnyamwamuta2@yahoo.com (P. A. Nyamwamu), vogemah@mmust.ac.ke (V. K. Ogemah), jmuoma@gmail.com (J. V. Muoma),Stephan.winter@dsmz.de (S. Winter), werehkde@yahoo.com (H. K. Were)

${ }^{*}$ Corresponding author

\section{To cite this article:}

Mariam Nyongesa Were, Benard Mukoye, Aggrey Keya Osogo, Bonphace Collins Mangeni, Paul Ateng'a Nyamwamu, Vitalis Kalor Ogemah, John Vincent Muoma, Stephan Winter, Hassan Karakacha Were. Occurrence and Distribution of Begomoviruses Infecting Cassava in Western Kenya. Plant. Vol. 4, No. 6, 2016, pp. 108-113. doi: 10.11648/j.plant.20160406.18

Received: September 29, 2016; Accepted: October 11, 2016; Published: November 7, 2016

\begin{abstract}
Cassava (Manihot esculenta Cranz) is an important food staple in Busia, Homabay, Siaya, Migori, Kwale, Kilifi and Marakwet Counties and is a secondary food crop for many Kenyans. The current yields of 3-4 tons/ha obtained in Western Kenya are far below world averages and this is largely attributed to pests and diseases. The usual practice of retaining some seed cuttings from the current ware crop or buying them from neighbours, leads to accumulation of viral diseases most important of which are caused by begomovirus infections. A survey for cassava mosaic disease (CMD) was carried out in main cassava growing areas of Western Kenya with a view to determine incidence and distribution of the causal viruses. A total of 33 cassava farms in seven sub-counties in Western Kenya were covered. Leaf samples were collected and analysed serologically and by molecular means. Cassava plants in most farms were severely affected by cassava mosaic disease. Disease incidence in farms ranged between $2 \%$ to $54 \%$. Three cassava infecting begomoviruses, African Cassava Mosaic Virus (ACMV), East African Cassava Mosaic Virus (EACMV) and East African Cassava Mosaic Virus - Ugandan variant (EACMV$\mathrm{Ug}$ ) were found in the collected samples, with EACMV-Ug being most prevalent followed by EACMV. These are interesting findings given that in the past surveys, ACMV was the most abundant virus in the area. To increase cassava yields, it is recommended that cassava farmers be educated on cassava diseases and their control.
\end{abstract}

Keywords: Begomoviruses, Western Kenya, Manihot Esculenta

\section{Introduction}

Cassava is an important staple food crop in Busia, Homabay, Siaya, Migori, Kwale, Kilifi and Marakwet Counties of Kenya and is a secondary food crop for many Kenyans whose staple diet is based on cereals, particularly maize [1]. Previous work [2] established that sweet-potato and cassava are important food security crops when maize, the major staple, is in short supply or in years of drought.

In urban areas there is a growing demand for good quality fresh cassava roots and for processed products such as flour and chips. Cassava is usually grown in rain fed, low-input systems and the yields obtained in Kenya of $11 \mathrm{t} / \mathrm{ha}$ [3] are among the poorest in the world compared to $20 \mathrm{t} / \mathrm{ha}$ in Nigeria and about 24t/ha on experimental stations. Cassava is propagated vegetatively through planting stem cuttings.

Although there are many constraints to production, every analysis has shown that the single most important constraint in the whole country is the lack of high quality disease-free planting material in the form of stem cuttings. A second 
important constraint is the lack of grower awareness and knowledge of pests and diseases or how to manage them. The usual practice of farmers to retain stem cuttings from the current crop being produced for consumption or buy them from a neighbour leads to high incidence of whitefly transmitted virus diseases namely, Cassava mosaic disease (CMD) and Cassava brown streak disease (CBSD). The causal viruses of CMD are: African cassava mosaic virusKenya (ACMV-K), and East African cassava mosaic virus (EACMV), East African cassava mosaic Zanzibar virus (EACMZV), Uganda variant strain of the EACMV (EACMV-Ug) and East African cassava mosaic Kenya Virus (EACMKV) while Cassava brown streak virus (CBSV) and Cassava brown streak Uganda virus (UCBSV) cause CBSD [4 -7]. These viruses are spread by whiteflies rapidly during the growing season or by infected cuttings in subsequent seasons. Incidences of up to $100 \%$ have been found in Kenya [8]. Moreover, if crops are grown in land contaminated by bacteria or nematodes the cuttings become infected leading to bacterial or nematode infection in subsequent generations.

Surveys done previously [4, 6, 8, 9] found ACMV, EACMV, EACMKV and EACMV-Ug as the most prevalent viruses in Western Kenya but no recent survey in the region to determine the status of CMD causal viruses has been done. This paper reports the results of a survey undertaken in the main cassava-growing regions of Western Kenya to monitor the dynamics of the relative prevalence of CMD begomoviruses.

\section{Materials and Methods}

\subsection{CMD Survey}

A diagnostic survey for CMD was conducted in Bungoma South, Busia, Homabay, Rachuonyo, Rongo, Teso South and Ugenya sub-counties of Western Kenya. Farms were surveyed during the long rains of May/June 2011 to take advantage of the vigorous vegetative growth of cassava at the time. Cassava fields were selected at regular intervals of between three and five kilometres along the main roads and occasionally feeder roads. The number of fields sampled per county depended on the availability of cassava farms at the time of survey. Sampling was done on plants along diagonals and the number of samples collected per field depended on the variability of symptoms and filed size. Disease incidence was calculated as a percentage of symptomatic plants to the total number of plants along the sampling diagonals. Coordinates were taken at each sampling site using a global positioning system (GPS) device (Magellan Triton 'Windows CE Core 5.0 X11-15302).

Visual symptoms were assessed as described earlier [8] and classed as mosaic, dwarfing, chlorosis, or a combination of these.

Data obtained from the surveys (altitude, and virus disease incidence) were recorded in Microsoft Excel spreadsheets, while correlation and regression analysis was done using the computer software Statistical Package for Social Scientists
(SPSS).

\subsection{Virus Detection by ELISA}

Leafy samples from 3 to 5 cassava plants per farm were collected and tested using Triple antibody sandwich enzyme linked immunosorbent assay (TAS-ELISA) as described previously [10] using polyclonal antibodies raised against CMD viruses for coating and monoclonal antibodies specific to ACMV and EACMV viruses for detection. Microtiter plates (Greiner Microlon medium binding) and reagents for the virus tests were obtained from the German collection of Microorganisms and Cell cultures (DSMZ), Braunschweig, Germany. Tests were done following the manufacturer's instructions. Each ELISA plate contained positive and negative control samples and samples were tested in single wells. Absorbance values were recorded at $405 \mathrm{~nm}$ (A405) using a Titertek Multiscan ${ }^{\circledR} \quad \mathrm{MCC} / 340$ model spectrophotometer (Labsystems Co., Finland).

Samples whose absorbance values (A405) exceeded the negative control values by a factor of two were considered positive. Some plates were scored visually and samples considered positive if the colour of substrate in the sample wells was clearly stronger than in the negative control wells.

\subsection{PCR-Mediated Amplification of Cassava Begomovirus Species DNA-A Fragments}

Total DNA was extracted from young virus-infected cassava leaves essentially as described by [11]. Amplification of viral sequences was done using degenerate universal geminivirus primers [12]. For detection and differentiation of cassava begomoviruses, ACMV, EACMV-Ug, sequences in single and in mixed virus infections, a polymerase chain reaction (PCR) approach was followed. PCR tests were conducted using primers specific for ACMV, EACMV and EACMV-Ug. For ACMV, (ACMV AL1/F, ACMV ARO/R [4], EACMV (EACMVA391/ EACMVA2469) and EACMVUg (UV AL1/F1/ ACMV CP/R3) [3] primer combinations were used. Amplification by PCR proceeded as follows: Total plant DNA $(1 \mu \mathrm{l})$ was subjected to PCR in a total reaction volume of $50 \mu \mathrm{l}$. The reaction consisted of $2.5 \mu \mathrm{l}$ $\mathrm{MgCl}_{2}, 1 \mu \mathrm{l}$ of 20 pmol of each primer, $5 \mu \mathrm{l}$ of $10 \mathrm{x}$ Taq polymerase buffer, $1 \mu \mathrm{l} 5 \mathrm{mM}$ dNTPs, and $0.5 \mu \mathrm{l}$ or 2.5 units of Taq DNA polymerase (Toyobo, Osaka, Japan). The cycling profile was $3 \mathrm{~min}$ of denaturation at $94^{\circ} \mathrm{C}$ followed by 35 cycles of denaturation, annealing and DNA extension of $1 \mathrm{~min}$ at $94^{\circ} \mathrm{C}, 1.5 \mathrm{~min}$ at $52^{\circ} \mathrm{C}$, and $1.5 \mathrm{~min}$ at $72^{\circ} \mathrm{C}$ respectively. A final extension period of $10 \mathrm{~min}$ at $72^{\circ} \mathrm{C}$ finished the PCR amplification.

\section{Results}

The surveyed farms were located between longitudes $0019085^{\circ} \mathrm{E}$ (a farm in Ugenya) and $9955378^{\circ} \mathrm{E}$ (a farm in Rachuonyo) and latitudes $0627200^{\circ} \mathrm{N}$ (a farm in Busia) and $091342^{\circ} \mathrm{N}$ (a farm in Rachuonyo). The lowest altitude of the surveyed farms was $1181 \mathrm{~m}$ above sea level (m asl) (a farm in 
Teso South) while the highest was 1496 m.asl (a farm in Rongo).

\subsection{CMD Symptoms and Incidence}

Symptoms observed in the field on cassava infected with CMD ranged from chlorotic spots, leaf curling, bright mosaic and stunting of severely affected plants.

Cassava mosaic disease was present in all the sub-counties surveyed. The highest CMD incidence (54\%) was observed in a farm in Bungoma South while a farm in Rongo had the lowest $(2 \%)$. The mean disease incidence was highest in Teso South $(30 \%)$ while Rongo had the lowest (11\%). Overall, the mean incidence for all the sub-counties surveyed was $19 \%$. (Fig. 1)

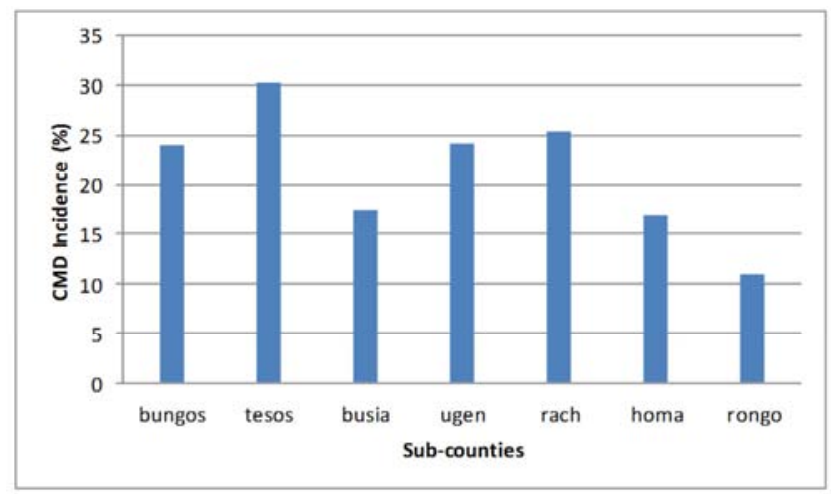

Figure 1. A bar graph showing mean CMD incidence per Sub-county.

Legend: bungos-Bungoma south, tesos- Teso South, busia - Busia, ugen Ugenya, rach, Rachuonyo, homa- Homabay, rongo, Rongo

\subsection{TAS-ELISA}

Of the 53 samples tested, 44 were positive for cassava begomoviruses. An interesting feature was that although most samples collected from all sub-counties had cassava begomoviruses, a few samples from Homabay (3 out of 7), Teso (4 out of 7) and Ugenya (2 out of 8 ) were negative. This was despite the fact that most samples collected had typical CMD symptoms. Furthermore, because ELISA could not differentiate between the begomoviruses, a PCR test was conducted.

\subsection{PCR}

Results of the PCR tests conducted using primers specific to ACMV, EACMV and EACMV-Ug detected ACMV, EACMV and EACMV-Ug in samples collected from all surveyed areas except Rongo where there was no EACMVUg (Table 1 and Fig.2). Mixed infections with all the three viruses (ACMV, EACMV and EACMV-Ug) were found in 9 of the 30 samples tested, ACMV and EACMV were in 7 samples while EACMV and EACMV-Ug, were in 9 samples. Two samples (from Rongo and Rachuonyo) had single EACMV infections while a sample from Bungoma South had a single infection with ACMV. It is interesting to note that EACMV-Ug was never found infecting cassava alone but was always in mixed infections either with the other two combined or with EACMV. EACMV was the most dominant virus (found in 26) of the 30 samples) followed by EACMV$\mathrm{Ug}$ found in 18 samples while ACMV occurred least in 17 samples. Surprisingly, asymptomatic cassava sample obtained from Ugenya as a healthy control, tested positive by ELISA and was also found to have mixed infection of ACMV, EACMV and EACMV-Ug by PCR analysis.

Table 1. TAS-ELISA and PCR results obtained from analysis of cassava samples for cassava begomoviruses.

\begin{tabular}{|c|c|c|c|c|c|c|c|c|c|c|}
\hline \multirow{2}{*}{ Sub-county } & \multicolumn{2}{|c|}{ ELISA } & \multicolumn{8}{|l|}{ PCR +ve } \\
\hline & +ve & -ve & \# Tested & $\mathbf{A}$ & $\mathbf{E}$ & $\mathbf{U}$ & $\mathbf{A}+\mathbf{E}$ & $\mathbf{A}+\mathbf{U}$ & $\mathbf{E}+\mathbf{U}$ & $\mathbf{A}+\mathbf{E}+\mathbf{U}$ \\
\hline Bungoma S. & 17 & 0 & 7 & 1 & 0 & 0 & 1 & 0 & 2 & 3 \\
\hline Busia & 5 & 0 & 2 & 0 & 0 & 0 & 0 & 0 & 0 & 2 \\
\hline Homabay & 4 & 3 & 4 & 0 & 0 & 0 & 2 & 0 & 2 & 0 \\
\hline Rachuonyo & 7 & 0 & 6 & 0 & 1 & 0 & 2 & 0 & 2 & 1 \\
\hline Rongo & 2 & 0 & 1 & 0 & 1 & 0 & 0 & 0 & 0 & 0 \\
\hline Teso S. & 3 & 4 & 6 & 0 & 0 & 0 & 1 & 0 & 2 & 2 \\
\hline
\end{tabular}

Legend: A=ACMV, E=EACMV, U=EACMV $-\mathrm{Ug}$

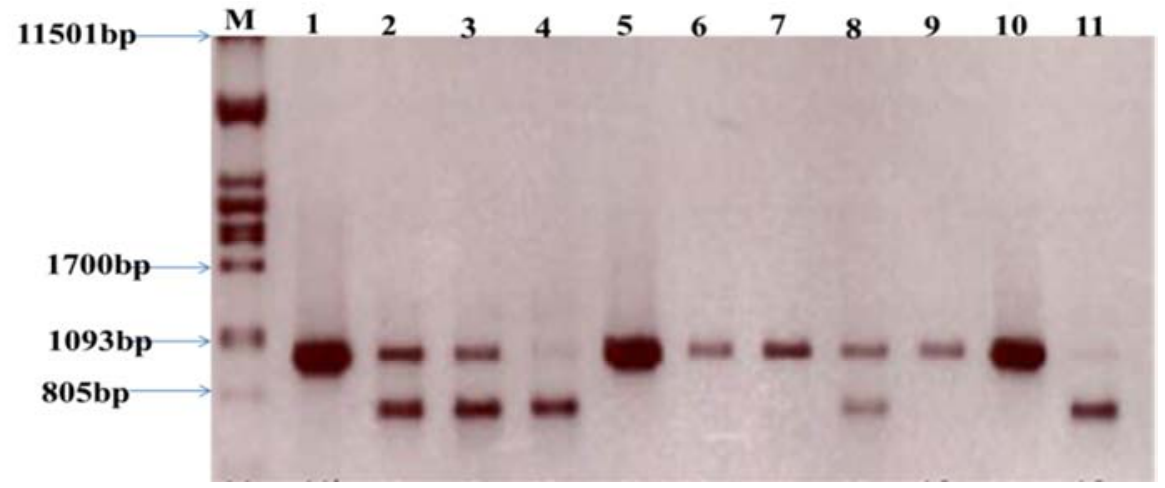




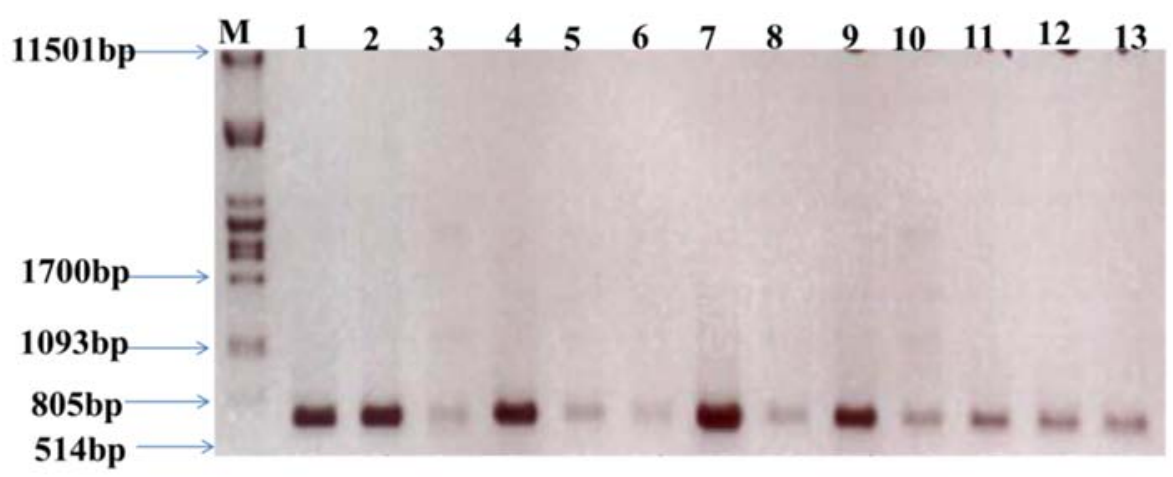

b

Figure 2. a. Gel electrophoresis of PCR amplification of cassava (ACMV\& EACMV-Ug) begomovirus DNA (expected band size: ACMV=975 bp, EACMV$U g=)$. Lanes 1 - 3; leaf samples from Bungoma South (11b, 12a and 12b), Lanes 4 and 5; Ugenya (13a and 13b), Lanes 6 and 7; Homabay (14a and 14b), Lane 8; Busia (15) and Lanes 9-10; Rachuonyo (16a and 16b). b. Gel electrophoresis of PCR amplification of cassava (EACMV) (expected band size $E A C M V=520 \mathrm{bp}$ ). Lanes 1 and 2; leaf samples from Bungoma South (12a and 12b), Lanes 3 and 4; Ugenya (13a and 13 b), Lanes 5 and 6; Homabay (14a and 14b), Lane 7; Busia (15), Lanes 8-10 and 13; Rachuonyo (16a, 16b, 16c and 18a), Lanes 11 and 12; Teso South (17a and 17b).

\subsection{Distribution of ACMV, EACMV and EACMV-Ug in Western Kenya}

Based on ELISA and PCR results, a distribution map of cassava begomoviruses occurring in Western Kenya was drawn (Fig.3). EACMV was the dominant virus found occurring in all surveyed areas followed by EACMV-Ug which, in all cases, was found in mixed infections. The other virus ACMV was only found alone in a sample from Bungoma South and was the least occurring virus in the region.

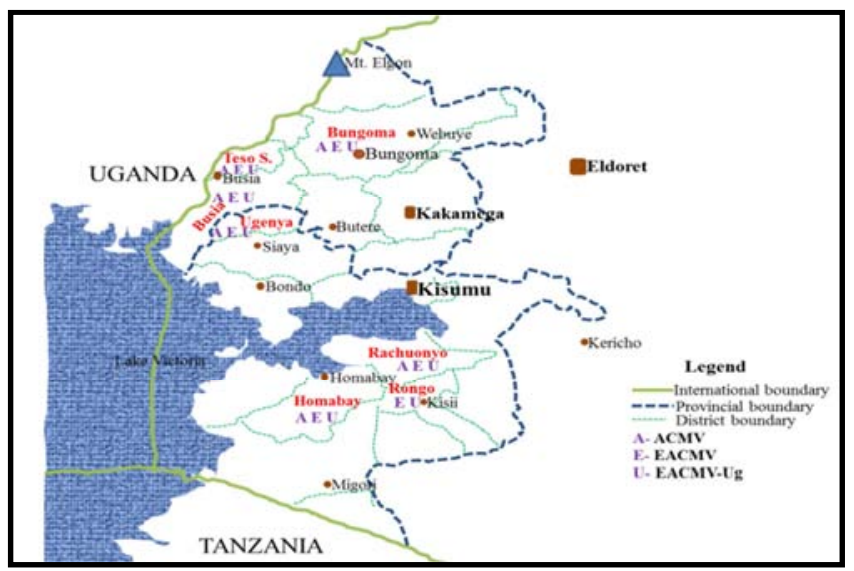

Figure 3. Map of Western Kenya (not drawn to scale) showing the distribution of $A C M V, E A C M V$ and EACMV-Ug in the surveyed areas (In red font).

\section{Discussion}

The highest CMD incidence was found to occur at levels of up to $54 \%$. Such levels are considerably high and continue to increase with successive croppings. Although [13] reported successful restoration of cassava production in Western Kenya after introduction of new varieties with resistance to CMD this study found some of these varieties with high CMD incidence. This could mean the varieties either had some resistance which had broken down or that they are susceptible to the Western Kenya strains of the begomoviruses. The other scenario could be that since material was new, it was clean and therefore needed time to get infected in the field. With the current practice of farmers planting cuttings immediately after harvest, an epidemic could erupt similar to that of the 1990s if nothing is done in the near future. Provision of clean planting material to farmers seemed to lower the spread of the disease an observation supported by [7] who observed that due to lack of sustainability in providing clean material arrangements, there is a conspicuous resurgence of the viral diseases again.

The CMD incidence was not significantly different among the surveyed districts. This implies that farmers in these areas get planting material from the same sources and cultural practices are similar. According to [14] and [15], variability in the pathological incidences of CMD is often attributed to several factors such as different strains of virus, susceptibility and age of the host plant and environmental factors such as solar radiation and temperature. Therefore, similar incidences witnessed in this study may be attributed to the fact that the surveyed sub-counties, though in different ecological zones, they had no significant difference in the altitudes. Furthermore, in addition to the weather conditions being the same, there was no significant difference in age of cassava crops. A striking feature of this study was that there was no farm with $0 \%$ CMD incidence, an indication that all cassava varieties in the surveyed area were susceptible to the viruses and that all farms were infected. Surprisingly, CMD was known to all farmers who were covered in the survey, but no single farmer looked keen to contain or try to do so by phytosanitary means. This is supported by the fact that most farmers used and recycled their own cuttings saved from a previous crop as source of planting material leading to propagation of the viruses if the parent material was infected. This confirms the findings by [15] that CMD appears to originate mostly from unhealthy cassava cuttings used for planting.

Several CMD causal virus species ACMV and EACMV and an EACMV variant EACMV-Ug, were detected by TAS- 
ELISA and by PCR. Although TAS-ELISA was cheap and relatively easy to carry out, it was not possible to differentiate the viruses using the method due to unavailability of monoclonal antibodies for EACMV-Ug and EACMKV. Moreover, viruses in mixed infections could not be differentiated hence the need for molecular diagnosis. However, with appropriate and high quality antisera, this method can be very useful in places where PCR is either not available or just expensive (reagents, equipment and expertise) to sustain. On the other hand, although the primers used for PCR were robust and very precise, they could not detect EACMKV or EACMZV. New additional primers need to be derived that can detect these viruses.

From PCR results, $83 \%$ of the positive cassava samples were infected with EACMV, 60\%, with EACMV-Ug and $57 \%$, ACMV. This makes EACMV and EACMV-Ug the most abundant viruses in Western Kenya. Before EACMV$\mathrm{Ug}$ was reported, Western Kenya was predominantly an ACMV zone with EACMV being geographically located along the coast or the Eastern side of the Rift valley. A few reports [8] had found EACMV in Kisii and Alupe, since then there has been no comprehensive surveys for the viruses in the area. It was reported then that EACMV-Ug was very virulent [4] and that it was displacing ACMV from ACMV traditional areas. This study has found ACMV to be the least predominant virus and confirms earlier workers [8] fears. However, it is not clear how ACMV has been displaced by EACMV and EACMV-Ug.

Some samples collected from variety TME 14 with no symptoms were found to have mixed infections of ACMV, EACMV and EACMV-Ug after PCR tests. This clearly shows that the viruses can be latent in the plant without symptoms manifestation. Such varieties may be tolerant to the viruses and planting them could be dangerous as this could act as a source of infection and could fuel the spread of the disease to more susceptible varieties.

With regard to distribution of begomoviruses in Western Kenya, the three begomoviruses (ACMV, EACMV and EACMV-Ug) were found to be widely distributed in the surveyed area. In all cases, mixed infections of these three viruses were detected in samples from most farms. EACMV was the most predominant virus followed by the strain EACMV-Ug. This slightly differs with earlier findings [16$18]$ that none of disease surveys conducted in Sub-Saharan Africa have reported the incidence of the EACMV virus suggesting that this 'wild-type' EACMV has been overtaken in nature by the more fit recombinant strains. Furthermore, since EACMV-Ug was first reported in Uganda in late 1980s, it has spread to affect nine countries in East and Central Africa [19, 20]). The reasons for this difference could be that none of the above surveys was done in Kenya, and since EACMV has never been reported in Uganda, it is not surprising that the findings confirm this view. In Western Kenya, all the three viruses were widespread in the entire surveyed area but EACMV-Ug has displaced most of the ACMV in most farms in Western Kenya as earlier predicted. [8].

\section{Conclusions}

CMD incidence is very high in Western Kenya, which requires urgent attention.

PCR is the most reliable and sensitive means of differentiating the begomoviruses, however, in places where the tests may not be possible by this means, TAS-ELISA may suffice if new MAbs are produced in line with the changing virus dynamics in the field.

All the three cassava begomoviruses (EACMV, EACMV$\mathrm{Ug}$ and $\mathrm{ACMV}$ ) are present in Western Kenya mainly in mixed infections. EACMV and EACMV-Ug have displaced ACMV from most of the areas that were traditionally occupied by the latter.

Farmers use own planting materials or those from neighbours most of which are not clean and therefore serve as source of virus.

For effective control of CMD, farmers need to be sensitized on the benefits of using clean planting material, which should be made available.

\section{Acknowledgments}

This study was funded by the National Commission for Science, Technology and Innovation (NACOSTI), Kenya (Ref. NCST/ST\&I/4 ${ }^{\text {th }}$ Call M.Sc/095).

\section{References}

[1] N. Gakonyo, (1993) "Processed sweet potato: Responding to Kenya's urban food needs of working papers in agricultural economics", Vol 93-99, 1993, Cornel University.

[2] J. N. Mutura, P. T. Ewel, A. Abubaker, T. Mungai, S. Ajanga, J. Irungu, F. Omari, and S. Maobe, "Sweet potatoes in the food systems of Kenya", Results of socioeconomic survey pp 55-66, 1992.

[3] H. K. Were, "Serological and Molecular Characterisation of begomoviruses infecting cassava (Mannihot esculenta Crantz) in Africa", PhD Thesis, 2001.

[4] X. Zhou, Y. Liu, L. Calvert, C. Munoz, G. W. Otim-Nape, D. J. Robinson, and B. D. Harrison, "Evidence that DNA A of a geminivirus associated with severe cassava mosaic disease in Uganda has arisen by inter-specific recombination”, Journal of General Virology, 78:210, 1997.

[5] J. P. Legg, and C. M. Fauquet, "Cassava mosaic geminiviruses in Africa", Plant Molecular Biology, 56: 585599, 2004.

[6] S. E. Bull, R. W. Briddon, S. W. Sserubombwe, K. Ngugi, P. G. Markham and J. Stanley, "Genetic diversity and phylogeography of cassava mosaic viruses in Kenya", Journal of General Virology, 87: 3053-3065, 2006.

[7] S. Winter, M. Koerbler, B. Stein, A. Pietruszka, M. Paape and A. Butgereit, "The analysis of cassava brown streak viruses reveals the presence of a distinct virus species causing brown streak disease in East Africa", Journal of General Virology, 91, $1365-1372,2010$. 
[8] H. K. Were, S. Winter and E. Maiss, "Viruses infecting cassava in Kenya", Plant Disease, 88:17-22, 2004.

[9] F. O. Ogbe, G. I. Atiri, A. G. O. Dixon and G. Thottappilly, "Symptom severity of cassava mosaic disease in relation to concentration of African cassava mosaic virus in different cassava genotypes”, Plant Pathology, 52:84-91, 2003.

[10] H. K. Were, J. Kabira, Z. M. Kinyua, F. M. Olubayo, B. Imbuga, J. Karinga, J. Aura, A. K. Lees, G. H. Cowan and L. Torrance, "Occurrence and distribution of potato pests and diseases in Kenya", Potato Research, 56:325-342, 2014.

[11] S. L. Dellaporta, J. Wood and H. B Hicks, "A plant DNA minipreparation: Version II", Plant Molecular Biology Reporter 1:19-21, 1983.

[12] R. W. Briddon, S. Liu, M. S. Pinner and P. G. Markham, "Infectivity of African cassava mosaic virus clones to cassava by biolistic inoculation", Archives of Virology, 143:24872492,1998

[13] H. M. Obiero, J. A. B. Whyte, J. P. Legg, M. S. Akhwale, J. Malinga and T. Magut, 2007. "Successful restoration of cassava production in Western Kenya", Proceedings of the $13^{\text {th }}$ ISTRC Symposium, pp. $682-685,2007$.

[14] R. J. Hillocks, J. M. Thresh and A. C. Belloti, "Cassava biology, production and utilization" CABI, Wallingford, pp 41-54, 2002.

[15] M. M. Manyi, K. N. Kabwe, B. Claude, T. D. Patrick, S. Winter and A. K. Mbuyi, "Incidence, Severity and Gravity of
Cassava Mosaic Disease in Savannah Agro-Ecological Region of DR-Congo: Analysis of Agro-Environmental Factors", American Journal of Plant Sciences, 3: 512-519, 2012.

[16] O. J. Alabi, F. O. Ogbe, R. Bandyopadhyay, P. L. Kumar, A. G. O. Dixon, J. d'A. Hughes and R. A. Naidu, "Alternate hosts of African cassava mosaic virus and East African cassava mosaic Cameroon virus in Nigeria", Archives of Virology, 153:1743-1747, 2008.

[17] W. S. Sserubombwe, R. W. Briddon, Y. K. Baguma, G. N. Ssemakula, S. E. Bull, A. Bua, T. Alicai, C. Omongo, G. W. Otim-Nape and J. Stanley, "Diversity of begomoviruses associated with mosaic disease of cultivated cassava (Manihot esculenta Crantz) and its wild relative (Manihot glaziovii Mull. Arg.) in Uganda”, Journal of General Virology, 89:17591769, 2008.

[18] S. E. Bull, J. Ndunguru, W. Gruissem, J. R. Beeching and H. Vanderschuren, "Cassava: constraints to production and the transfer of biotechnology to African laboratories", Plant Cell Rep. doi:10.1007/s00299-010-0986-6, 2011.

[19] J. P. Legg, "Emergence, spread and strategies for controlling the pandemic of CMVD in E. Africa", Crop protection 18: 627-637, 1999.

[20] J. P. Legg, B. Owor, P. Sseruwagi and J. Ndunguru, "Cassava mosaic virus disease in East and Central Africa: Epidemiology and management of a regional pandemic", Advances in Virus Research, 67: 355-418, 2006. 